\title{
Entrepreneurial exit in real and imagined markets
}

\author{
Erik Stam*, Roy Thurik** and Peter van der Zwan ${ }^{\dagger}$
}

Entrepreneurs exit their businesses due to selection pressures they experience in the market place. In addition to this well-known ex-post decision to exit, entrepreneurs select ex-ante whether they are willing to pursue an entrepreneurial career at all, or to give up their entrepreneurial intentions. Hardly anything is known about the latter selection process in imagined markets that precedes the creation of variation and selection process in real markets. This article explores these two selection processes using survey data on 20,000 individuals in 27 European countries and the United States in 2007. We distinguish business failure from exit by sell-off. Individuals in the United States are less likely to exit imagined markets and are more likely to exit the real market than are Europeans. Individuals in a corporatist welfare state regime have relatively high chances to exit imagined markets but low chances to exit real markets (due to failure). Business owners in metropolitan and urban environments are more likely to fail than their rural counterparts, while individuals with a high risk tolerance and individuals with a self-employed parent are less likely to exit imagined or real markets (via business failure). In short, this study shows that exit in real and in imagined markets is differently affected by individual characteristics as well as by the competitive and institutional environment.

${ }^{\star}$ Erik Stam, Tjalling Koopmans Institute, Utrecht School of Economics, Utrecht University, Janskerkhof 12, 3512 BL Utrecht, The Netherlands; Centre for Technology Management, University of Cambridge, Cambridge, UK; and Max Planck Institute of Economics, Jena, Germany. e-mail: e.stam@uu.nl

${ }^{*}$ Roy Thurik, Centre for Advanced Small Business Economics, Erasmus School of Economics, Erasmus University Rotterdam, P.O. Box 1738, 3000 DR Rotterdam, The Netherlands; EIM Business and Policy Research, Zoetermeer, The Netherlands; and Max Planck Institute of Economics, Jena, Germany. e-mail: thurik@ese.eur.nl

†Peter van der Zwan, Centre for Advanced Small Business Economics, Erasmus School of Economics, Erasmus University Rotterdam, P.O. Box 1738, 3000 DR Rotterdam, The Netherlands. e-mail: vanderzwan@ese.eur.nl 


\section{Introduction}

Entrepreneurs are important drivers of variation in the economy (Metcalfe, 1997; Baumol, 2002). Without variation, there is no selection or learning and hence no economic progress (Audretsch et al., 2004). Economic progress hinges on the essential mechanisms of the creation of variation and the operation of selection. Creation of variation is often analyzed by investigating the entry of new firms, whereas selection is analyzed by investigating the exit of incumbent firms (ex-post selection). In the evolutionary approach, the creation of new organizations does not only involve new variation but also includes ex-ante selection, as the persons involved evaluate whether an opportunity can be turned into a business, which is sufficiently profitable in the sense that its foundation offsets the (opportunity) costs involved. However, pre-entry market selection (ex-ante selection) has hardly received any attention (Barnett et al., 2003). Two environmental characteristics drive the entry decision: the munificence of opportunities and the availability of resources. The combination of these two characteristics and the individual's evaluation of the potential business make the nascent entrepreneur decide to start a firm. Without opportunities, persons will not be triggered to take any action to start a new firm, and without resources, nascent entrepreneurs are likely to be frustrated in the pursuit of the opportunities.

Post-entry market selection is a much better researched phenomenon (Mata and Portugal, 1994; Mata et al., 1995) than pre-entry market selection. An important reason for the lack of empirical research on ex-ante selection processes resides in the difficulty of obtaining data about nascent entrepreneurs (Reynolds, 1997; Van Gelderen et al., 2005) or pre-producer firms (Jovanovic, 2004; Carroll and Khessina, 2005). In other words, there is little available information about the risk set from which entry selection processes must be selected. Such studies require drawing samples of individuals from the entire population (instead of census-based firm data), which is often difficult for researchers to accomplish. This also involves a shift of level of analysis from the firm to the person (Scott and Rosa, 1996; Shane and Khurana, 2003).

A theoretical reason for the neglect of ex-ante selection is that in mainstream economics, ex-ante and ex-post selection are often treated as being close to observationally equivalent: ex-ante selection by rational actors and ex-post market selection are said to deliver the same outcomes. This assumes that foresight is perfect. According to Alchian (1950), the probability of entry and the probability of survival are likely to be interrelated. However, the presence of uncertainty and incomplete information (i.e. the absence of perfect foresight) makes it likely that these two probabilities differ. In the organizational ecology paradigm, two selection processes are distinguished that do not necessarily align: involuntary unemployment or forced retirement can be expected to increase the likelihood of attempting to found a new business but may not increase its odds of success, and conversely, a strong regulatory 
regime may decrease the rate of attempts but increase the success rate of those that do (Carroll and Khessina, 2005). Widely held notions of bounded rationality also suggest that while expectations about the future may guide individual behavior, common social situations are filled with uncertainty, ambiguity, and imperfect information, thereby making the equation of ex-ante with ex-post selection unrealistic (compare the distinction between intrafirm selection and market selection, which can be traced back to Nelson and Winter, 1982). The economics profession in general focuses on revealed preferences (ex-post selection) instead of stated preferences and the decision process that precedes the revealed preference (ex-ante selection). This drives the study of the differences between pre-entry and post-entry market selection outside the scope of the dominant debates.

In a societal context, both types of exits are highly relevant. Exit before business start-up does have positive consequences: it could prevent excess entry (Camerer and Lovallo, 1999), overinvestment, and the waste of resources. However, a negative consequence might be the absence of experimentation (new variety) and (entrepreneurial) learning. Exit after business start-up might have private losses and the waste of resources (in the form of sunk costs) as a negative consequence but possible individual and vicarious learning about entrepreneurship and markets (Knott and Posen, 2005) as a positive result. These negative consequences are not present when the firm exits via a sell-off: resources are not wasted with this mode of exit, and it might even include private gains (Holmes and Schmitz, 1990; Stam et al., 2008). People that have faced the market with their own business are likely to be better informed about markets than those who have never entered the market with their own business. Market forces provide feedback to entrepreneurs in a more immediate, concrete, and blunt way than many other settings where expertise is attained. This is why "market experience" may have positive learning effects beyond the life of the entrepreneur's firm (Stam et al., 2008).

In this article, we analyze both ex-ante and ex-post selection processes using a large survey of the European and US adult population. We define entrepreneurship as having the intention or taking efforts to become a business owner, or currently owning a business (Hyytinen and Ilmakunnas, 2007). Exit before business start-up (ex-ante selection) depends on the market expectations of the nascent entrepreneur (imagined markets), while exit after business start-up (ex-post selection) is more likely to be affected by the (revealed, real) market selection process. There has been a long debate in industrial economics and organizational ecology on selection processes (Alchian, 1950; Winter, 1971; Geroski, 2001; Barnett et al., 2003). However, research in these fields generally only includes revealed preferences. Our study also takes stated preferences and the decision to exit the population of nascent entrepreneurs into account. More specifically, these two exit processes are closely related to recent debates in research on the recognition, evaluation, and exploitation of entrepreneurial opportunities (Shane and Venkataraman, 2000). There has been 
much research on the recognition and exploitation of opportunities but little is known about their evaluation. This evaluation can be done by the entrepreneur, which may lead to giving up the pursuit of a business opportunity. Better known is the evaluation by the market, i.e. the external selection environment of businesses already in operation, which may lead to the closure of a business. The two selection processes can also be conceived as two types of exit from the entrepreneurial process: (i) Exit after opportunity recognition ("I thought of starting a business, or I had already taken steps to start a business, but gave up"); and (ii) Exit after opportunity exploitation. This second type of exit is investigated under two circumstances: "I once started a business, but currently I am no longer an entrepreneur since business has failed," and "I once started a business, but currently I am no longer an entrepreneur since business was sold, transferred, or closed." The first option is the best indicator of market selection.

The contributions of this article are the analyses of the role of ecological and personal characteristics in ex-ante and ex-post market selection and of the differences in the explanations of entrepreneurial exit in imagined and real markets, respectively. In addition, we refine the exit in real markets by distinguishing between exit due to business failure and exit due to sell-off. We take into account characteristics related to personality and human capital, while the ecological characteristics reflect levels of environmental munificence, levels of competition, and welfare state arrangements. Unlike prior studies with an evolutionary approach, we do not take the organization as the unit of selection; instead, we focus on the (potential) entrepreneur who has specific cognitive and other abilities. There are at least two arguments in favor of taking the individual person instead of the firm as the level of analysis: first, in the case of ex-ante selection, a firm does not (yet) exist, and second, most firms-even in advanced capitalist economies-are dominated by the entrepreneur. In Europe, the majority of formally registered firms involve less than two persons (European Commission, 2004). By combining both personal and ecological factors, we bring together the traits and rates approaches (Aldrich and Wiedenmayer, 1993).

The main research question in this article is "How can entrepreneurial exit in real and imagined markets be explained?" In addition we will discuss the differences between the explanation of exit in real markets and in imagined markets. The article starts with a discussion of the causes of entrepreneurial exit in real and imagined markets. Next, the data and method are presented. In the succeeding section, we present and interpret the outcomes of our empirical study. The article ends with our conclusion.

\section{Entrepreneurial exit}

Once the entrepreneur has entered the market with her new firm, she has to face the real-and not just the imagined-market selection. Most research, particularly in economics, has studied the (relative) importance of firm- and industry-specific 
variables explaining firm exit. Some stylized facts in this tradition are that firm exit is negatively related to firm (start-up) size, firm age, the number of plants operated by the firm, and the industry growth rate, and firm exit is positively related to the extent of entry in the industry (Mata and Portugal, 1994; Ilmakunnas and Topi, 1999).

However, to understand new firm formation (including pre-entry market selection) and survival, one must understand the way individuals aspire and take action to start a firm (Shane and Khurana, 2003). In their analysis of firm survival, Cefis and Marsili (2005) also make a plea for taking into account the characteristics of entrepreneurs when explaining the survival of new firms. The few economic studies of firm exit that consider personal characteristics find ambiguous effects of age and a negative effect of several kinds of human capital, such as general education and industry experience (Bates, 1990; Van Praag, 2003). There has been some research outside economics on the relationship between the entrepreneur's personality and firm exit (Ciavarella et al., 2004), but knowledge of the relation between personal characteristics and firm exit remains scarce. In the present article, we focus on entrepreneurial exit, i.e. the decision to quit an entrepreneurial career. This is not necessarily the same as firm exit because entrepreneurs may own several firms at the same time ("portfolio entrepreneurship") or successively ("serial entrepreneurship"), or individuals may quit their entrepreneurial career by selling their business.

Many people never think about being an entrepreneur. This group of individuals can hardly be thought of as being at risk of becoming an entrepreneur or as being confronted with market forces in a process of economic selection (Alchian, 1950). However, this particular group cannot be neglected in the analysis of entrepreneurial exit, which will be shown later. Undoubtedly, people who are thinking about starting a business (Blanchflower et al., 2001; Grilo and Irigoyen, 2006; Grilo and Thurik, 2008), or who are even taking steps to start a business (Reynolds, 1997; Davidsson, 2006), are at risk of becoming an entrepreneur (nascent entrepreneurs). They have to take into account the market forces that confront them after the business has been started. This implies that they have to develop expectations about the market forces that will eventually determine the viability of their future business. The closer they come to the entry of the market, the more likely they will have developed an image of the selection environment. This suggests that individuals who have started a business have better insights into the selection environment than individuals that are only thinking or trying to set up a business. Studies on nascent entrepreneurship have focused mainly on individual-level explanations. We will explicitly take into account different elements of the environment, such as the perceived resource availability of the environment, the degree of urbanization (a proxy for resource availability and competition), and the national institutional system. This latter element relates to a study by Henrekson (2005), which shows how key welfare state institutions tend to reduce economic incentives for entrepreneurship.

In order to explain exit in real and imagined markets, we compare persons who currently own a business with persons who no longer own a business and persons 
who aspire and take steps to start a business with persons who have given up these entrepreneurial aspirations and efforts. In the next two sections we will discuss the potential personal- and ecological-level drivers of exit in imagined and real markets.

\subsection{Personal characteristics}

Determining the effects of individual characteristics on imagined and real market exit requires taking into account the effect of the specific variable on the probability of experiencing imagined and real market conditions, respectively. Therefore, we simultaneously include these two principles in one model formulation. Hence, we are also able to analyze the influence of individual characteristics on experiencing imagined and real market conditions.

Risk tolerant persons are more likely to experiment. Thus, they are more likely to consider and exploit nascent activities. Earlier research has already shown that risk tolerance matters for having entrepreneurial preferences (Grilo and Thurik, 2005; Grilo and Irigoyen, 2006) and entry into self-employment (Van Praag and Cramer, 2001; Cramer et al., 2002; Ekelund et al., 2005; Caliendo et al., 2009). It can also be expected that they have a higher chance of once having closed a business because they pursue less certain and, on average, lower quality opportunities than risk-averse individuals. At the same time, because of the lower threshold of recognizing an opportunity for risk-tolerant individuals, the exploitation of the recognized opportunity could be not as easy as expected, which may lead to a higher likelihood of exit in imagined markets. ${ }^{1}$

On the one hand, highly educated people are more likely to develop the necessary skills for realizing their entrepreneurial ideas and running a business successfully. However, on the other hand, they are also more likely to face high opportunity costs in comparison to wage labor and thus exit. Both ex-ante and ex-post selections are likely to be affected by opportunity costs (Amit et al., 1995), i.e. alternative job market opportunities. Exit after business start-up is especially likely to be affected by the aspiration level of the entrepreneur (Baldwin and Rafiquzzaman, 1995; Gimeno et al., 1997). The outcome of the trade-off between improved skill levels and higher opportunity costs due to high levels of education is an empirical issue. With regard to nascent entrepreneurs, Parker and Belghitar (2006) found a negative effect of education on exit, while Van Gelderen et al. (2005) found no effect of education on exit. There has been more research on the effect of education on exit in real markets: two studies have found a negative effect of education on entrepreneurial exit (Bruce, 2002; Burke et al., 2008), but other studies have either found no effect (Taylor, 1999; Van Praag, 2003; Schäfer and Talavera, 2009) or have found a positive effect (Blanchflower and Meyer, 1994). Given the unclear trade-off between

\footnotetext{
${ }^{1}$ The authors would like to thank one of the anonymous reviewers for suggesting this effect of risk tolerance on exit in imagined markets.
} 
improved skill levels and higher opportunity costs, we do not anticipate a clear-cut effect of education upon entrepreneurial exit (Van der Sluis et al., 2005) in either imagined or real markets.

Persons with self-employed parents will be more committed to entrepreneurship due to both social norms and the entrepreneurial skills that they have acquired (Aldrich and Kim, 2007). This means that they will be less likely to exit than persons without self-employed parents. Lentz and Laband (1990) found that, for self-employed individuals, acquisition of entrepreneurial human capital occurs primarily through experience and that the sons and daughters of the self-employed benefit greatly from early exposure to their parents' business establishments and subsequently decide to go into business themselves. Cooper (1993) found that having parents who owned a business appeared to increase the probability of firm survival, and Burke et al. (2008) found that a self-employed father increased persistence in an entrepreneurial career.

Young persons are more likely to be adventurous and experimenting than older people, which makes them more likely to think about becoming or take steps to become an entrepreneur (Lévesque and Minniti, 2006; Davidsson, 2006). This 'age' effect may largely be covered by levels of risk tolerance, ${ }^{2}$ or overconfidence (Forbes, 2005). Parker and Belghitar (2006) and Van Gelderen et al. (2005) found no significant effect of age on exit in imagined markets. Once they have started, young people are more likely to exit because they have less experience and more alternative labor market opportunities. Several studies, however, found a negative effect of age on exit in real markets (Evans and Leighton, 1989; Blanchflower and Meyer, 1994; Holtz-Eakin et al., 1994; Taylor, 1999; Van Praag, 2003). This latter outcome can be explained by the combined effect of two mechanisms: age increases the human capital of the individual and thus should have a positive effect on the survival of the business, and age lowers the possibility of returning to employment (due to fewer labor market alternatives: Cooper, 1993), making the shift to a wage-earner career less likely. Evans and Leighton (1989) found very high exit rates for young persons, which reaches a plateau after the age of 30 years. Schäfer and Talavera (2009) found that individuals are more likely to quit self-employment at young and elderly ages. When we take the retirement age of individuals into account, we expect a slightly U-shaped curve, with increasing chances of exit by sell-off (e.g. with a business transfer) at the right-hand side of the curve.

\subsection{Ecological characteristics}

The ecologies in which entrepreneurs are active differ in their level of resource munificence and competition, which are expected to have negative and positive

\footnotetext{
${ }^{2}$ In more general terms, neuropsychological research found that age is negatively related to risk tolerance (Deakin et al., 2004).
} 
effects on exit, respectively. Box (2008) stresses the importance of the influence of environmental forces on exit. Munificent environments are likely to lower the barriers to entry and the chances of exit. We expect that indicators of perceived constraints in the environment are related to giving up entrepreneurial intentions and efforts and to closing a business as well.

These perceived environmental constraints may be caused by a lack of resources in the environment or by a lack of access to resources. This latter cause relates to the legitimacy of the entrepreneur's activities (Hannan and Freeman, 1984; Delmar and Shane, 2004): in certain environments the activities of new firms are regarded as relatively less reliable and accountable than in other environments. This constrains their access to the necessary resources to realize a new firm and to survive in competition with established firms. This legitimacy effect is most likely reflected in the perceived lack of financial support and perceived difficulty of obtaining sufficient information.

Market opportunities, resources, and competition are, in general, more concentrated in metropolitan and urban areas than in rural areas. The availability of resources and/or social networks that provide access to these resources (Sørenson and Sorenson, 2003; Stuart and Sorenson, 2003) makes it less likely that entrepreneurial intentions and efforts are constrained in metropolitan and urban areas. The large concentration of entrepreneurs in these areas also lowers the ambiguity attached to entrepreneurship and promotes its choice as a viable source of revenues (Minniti, 2005). An interesting related research question is whether the high levels of competition have a stronger effect on ex-ante selection than on ex-post selection. Because of this competition element, metropolitan in particular, but also urban areas, are likely to have a positive effect on exit in real markets (Huiban, 2010). Competition is more likely to be experienced in real markets than in imagined markets, so we do not expect an effect (or perhaps only a small effect) of the competition element on giving up entrepreneurial intentions or efforts. ${ }^{3}$

Many studies on entrepreneurship and firm exit use evidence from a single country to identify the role of economic institutions or policy. A cross-country set of micro-level data provides better identification of the effect of different institutional settings (Bartelsman et al., 2005; Reynolds et al., 2005). Welfare state institutions tend to reduce economic incentives for entrepreneurship (Henrekson, 2005). So, even if people are thinking about or taking steps toward starting a business in countries with strong welfare states, they are more likely to give up their entrepreneurial intentions and efforts because these are less likely to pay off in comparison to wage labor in such systems. Strong welfare states also discourage risky businesses,

\footnotetext{
${ }^{3}$ There might also be more job opportunities in urban areas, which has a positive effect on exit in real markets (i.e. exchanging an entrepreneurial career for a better paid wage earner career).
} 
and such environments may have a positive effect on the survival of existing businesses. ${ }^{4}$

\section{Data, measurement and method}

The data we use come from the 2007 "Flash Eurobarometer Survey on Entrepreneurship, No. 192" of the European Commission, originally consisting of 20,674 observations from 25 Member States of the European Union ${ }^{5}$ as well as Iceland, Norway, and the United States. Randomized telephone interviews were conducted by the Gallup Organization Hungary/Europe between January 9 and January 16, 2007 with respondents aged 15 years and over. In many European countries and in the United States, the target sample size amounted to 1000 respondents. However, in Austria, Cyprus, Denmark, Estonia, Finland, Iceland, Ireland, Latvia, Lithuania, Luxembourg, Malta, Norway, Slovakia, Slovenia, and Sweden, the target size was 500. Small variations around these target sample sizes may occur across countries. ${ }^{6}$

The following question forms the basis for the explanation of both types of exit: "Have you ever started a business or are you taking steps to start one?" In total, 20,474 out of 20,674 individuals answered either "no" $(15,462)$ or "yes" (5012) to this question. After having answered "no", respondents were redirected to a follow-up question in which they were confronted with the following three mutually exclusive options for characterizing their answers (the number of observations corresponding to each option is also given, next to the abbreviation we will use for each option in the remainder of this manuscript):

"No, it never came to your mind to start a business." ("never considered"; 9812 observations)

"No, but you are thinking about it." ("thinking"; 2298)

"No, you thought of it or you had already taken steps to start a business but gave up." ("gave up”; 2687)

Note that 665 respondents (out of 15,462) did not qualify their initial "no" answer. Individuals that initially answered "yes" had to choose one of the following five options:

"Yes, you are currently taking steps to start a new business." ("taking steps"; 770)

\footnotetext{
${ }^{4}$ Weak welfare states, like the United States and the UK, have less stringent regulations concerning the start-up of firms, which leads to relatively low entry and exit costs (Nicoletti et al., 1999).

${ }^{5}$ Romania and Bulgaria (EU Member States since 2007) are not included in the data set.

${ }^{6}$ For more background information on this data set (including the English questionnaire), we refer to the following website of the European Commission: http://europa.eu.int/comm/ enterprise/enterprise_policy/survey/eurobarometer_intro.htm.
} 
"Yes, you have started or taken over a business in the last 3 years which is still active today." ("young business"; 629)

"Yes, you started or took over a business more than 3 years ago and it is still active." ("mature business"; 1299)

"Yes, you once started a business, but currently you are no longer an entrepreneur since business has failed." ("failure"; 505)

"Yes, you once started a business, but currently you are no longer an entrepreneur since business was sold, transferred, or closed." (“sell-off”; 1400)

Note that 409 individuals (out of 5012) did not answer this follow-up question. Hence, for 19,400 individuals it is known to which of the eight categories they belong.

Each of the eight options represents a different level of involvement in the entrepreneurial process, ranging from no familiarity with self-employment at all to exit in real markets. Grilo and Thurik (2008) refer to these categories as "engagement levels". 7 The two engagement levels describing real exit distinguish between successful entrepreneurs who retired, transferred their business (perhaps they have recognized a better opportunity), or profitably sold their business, and entrepreneurs with a failed business. The first type of real firm exit cannot be regarded as a straightforward outcome of market selection.

Individuals that have given up their aspirations or efforts may have experienced earlier real market conditions. Also, if a respondent does not answer "failure" or "sell-off", this does not necessarily mean that he/she had not closed a business before: currently thinking about entrepreneurship or taking steps may mask prior (or present) business ownership. Also, being a current business owner does not exclude having closed a business before (as with serial or portfolio entrepreneurs; see Westhead and Wright, 1998).

For all countries, the percentages across all engagement levels are given in Table 1. Note that the total number of observations in this table equals 19,400. Clear differences between the European countries and the United States can be observed. In the United States, 30\% never considered setting up a business, while in the European countries this percentage amounts to 52. The "thinking" and "taking steps" percentages in Europe are considerably lower than in the United States (unweighted averages of $11 \%$ and $4 \%$ versus $21 \%$ and $9 \%$, respectively). Concerning imagined exit, $14 \%$ had given up his/her aspirations or efforts to start a business in Europe, sharply contrasting the 9\% for the United States. Furthermore, large variation occurs in the "sell-off" category: the United States, the Scandinavian countries, Cyprus, and Greece stand out with high percentages. Further inspection

\footnotetext{
${ }^{7}$ Note that Grilo and Thurik (2008) make no distinction between real exit due to business failure and real exit due to sell-off.
} 
Table 1 Percentages per entrepreneurial engagement level per country

\begin{tabular}{|c|c|c|c|c|c|c|c|c|c|}
\hline & $\begin{array}{c}\text { Never } \\
\text { considered }\end{array}$ & Thinking & $\begin{array}{l}\text { Taking } \\
\text { steps }\end{array}$ & $\begin{array}{l}\text { Gave } \\
\text { up }\end{array}$ & $\begin{array}{c}\text { Young } \\
\text { business } \\
\text { (<3 years) }\end{array}$ & $\begin{array}{l}\text { Mature } \\
\text { business } \\
\text { (>3 years) }\end{array}$ & Failure & $\begin{array}{l}\text { Sell- } \\
\text { off }\end{array}$ & $\begin{array}{l}\text { Obser- } \\
\text { vations }\end{array}$ \\
\hline Austria & 57 & 7 & 2 & 21 & 2 & 5 & 1 & 5 & 475 \\
\hline Belgium & 63 & 6 & 3 & 9 & 2 & 7 & 2 & 7 & 897 \\
\hline Cyprus & 40 & 15 & 3 & 12 & 5 & 11 & 4 & 11 & 493 \\
\hline Czech & 49 & 13 & 4 & 18 & 3 & 8 & 3 & 3 & 910 \\
\hline \multicolumn{10}{|l|}{ Republic } \\
\hline Denmark & 47 & 20 & 3 & 12 & 2 & 5 & 3 & 8 & 495 \\
\hline Estonia & 59 & 9 & 6 & 9 & 4 & 8 & 3 & 3 & 451 \\
\hline Finland & 56 & 6 & 2 & 10 & 3 & 9 & 2 & 12 & 419 \\
\hline France & 57 & 10 & 3 & 17 & 2 & 4 & 1 & 7 & 983 \\
\hline Germany & 48 & 12 & 4 & 20 & 4 & 6 & 2 & 5 & 966 \\
\hline Greece & 36 & 15 & 2 & 14 & 8 & 11 & 4 & 10 & 989 \\
\hline Hungary & 53 & 14 & 3 & 6 & 2 & 10 & 4 & 7 & 983 \\
\hline Iceland & 41 & 14 & 5 & 9 & 4 & 14 & 2 & 12 & 442 \\
\hline Ireland & 49 & 13 & 4 & 12 & 4 & 7 & 4 & 6 & 477 \\
\hline Italy & 56 & 7 & 4 & 15 & 3 & 5 & 2 & 8 & 941 \\
\hline Latvia & 50 & 25 & 6 & 1 & 3 & 6 & 3 & 6 & 451 \\
\hline Lithuania & 61 & 14 & 6 & 4 & 2 & 5 & 3 & 4 & 471 \\
\hline Luxembourg & 55 & 8 & 3 & 20 & 3 & 4 & 2 & 6 & 462 \\
\hline Malta & 63 & 8 & 1 & 24 & 1 & 2 & 0 & 1 & 434 \\
\hline Netherlands & 52 & 8 & 4 & 18 & 4 & 5 & 2 & 8 & 937 \\
\hline Norway & 58 & 11 & 2 & 8 & 3 & 9 & 1 & 8 & 461 \\
\hline Poland & 45 & 14 & 6 & 15 & 2 & 8 & 4 & 6 & 963 \\
\hline Portugal & 58 & 4 & 3 & 15 & 5 & 5 & 3 & 7 & 969 \\
\hline Slovakia & 43 & 27 & 5 & 12 & 2 & 5 & 3 & 4 & 479 \\
\hline Slovenia & 55 & 13 & 1 & 18 & 2 & 3 & 2 & 5 & 492 \\
\hline Spain & 57 & 8 & 3 & 14 & 3 & 6 & 3 & 6 & 964 \\
\hline Sweden & 45 & 15 & 6 & 12 & 3 & 5 & 2 & 11 & 478 \\
\hline UK & 47 & 8 & 5 & 20 & 3 & 5 & 2 & 9 & 971 \\
\hline Europe & 52 & 11 & 4 & 14 & 3 & 7 & 3 & 7 & 18,453 \\
\hline United States & 30 & 21 & 9 & 9 & 4 & 8 & 4 & 14 & 947 \\
\hline $\begin{array}{l}\text { Europe }+ \\
\text { United States }\end{array}$ & 51 & 12 & 4 & 14 & 3 & 7 & 3 & 7 & 19,400 \\
\hline
\end{tabular}

Source: "Flash Eurobarometer Survey on Entrepreneurship, No. 192" (conducted in 2007). 
shows that the differences between the eight post-communist Member States and the other 19 European countries are relatively small (these percentages are omitted from Table 1). For example, in the post-communist countries, 51\% reported "never considered", while 52\% gave this answer in the other European countries. The "thinking" and "taking steps" categories represent 16\% and 5\% of the respondents in the post-communist and $10 \%$ and $3 \%$ in the other European countries.

We realize that the "method of moment inequalities" to investigate market entry and exit dynamics would be a sensible candidate for our purposes (Pakes et al., 2005). The assumption of this method is that agents behave according to maximization of their expected returns. An approximation of realized profits from the actual choice strategy undertaken by the individual and at least one other feasible alternative is required. However, we do not have information about the expected profits of the realized strategy or the choice that has not been undertaken, or about any other approximation. Therefore, we will not use the method proposed in Pakes et al. (2005). Instead, given the categorical nature of the data, we make use of a multinomial logit model (McFadden, 1973) to examine how and in what way exit in imagined markets differs from exit in real markets.

The advantage of using a multinomial logit model is that it includes all eight engagement levels. For each engagement level, the model predicts the probability that an individual belongs to that particular engagement level. Individuals belonging to "never considered" cannot be neglected with respect to explaining the probability of exiting the imagined or real market place. It may well be that respondents that have never considered setting up a business have a likelihood (albeit probably small given the small values of their explanatory variables) of being active in the imagined and/or real market place.

First, we compare persons that gave up their entrepreneurial intentions or efforts with persons that currently have entrepreneurial intentions or are taking steps to start a business. In our multinomial logit set-up, we merge the engagement levels "thinking" and "taking steps" and take these two engagement levels as the reference category. Interpretation in a multinomial logit model is always done relative to a particular reference category. Then, we are able to investigate the effects of the personal and ecological characteristics on the odds (ratio of two probabilities) of the engagement level "gave up" relative to the reference category (i.e. "thinking" and "taking steps"). To be more precise, we attempt to clarify which personal and ecological characteristics increase or decrease the likelihood that an individual has exited the imagined market place relative to currently being active in this imagined market place.

Second, we contrast persons that have closed their business, either successfully or unsuccessfully, with persons that currently own a business. In this case, we merge the engagement levels "young business" and "mature business" and take these two engagement levels as the reference category in our multinomial logit model. The analysis of exit in real markets amounts to two exercises: we do not only investigate 
Table 2 Set-up of multinomial logit model

\begin{tabular}{|c|c|c|c|c|c|c|c|c|}
\hline $\begin{array}{l}\text { Engagement } \\
\text { levels: }\end{array}$ & $\begin{array}{l}\text { Never } \\
\text { considered }\end{array}$ & Thinking & $\begin{array}{l}\text { Taking } \\
\text { steps }\end{array}$ & Gave up & $\begin{array}{l}\text { Young } \\
\text { Business } \\
\text { (<3 years) }\end{array}$ & $\begin{array}{l}\text { Mature } \\
\text { Business } \\
\text { (>3 years) }\end{array}$ & Failure & Sell-off \\
\hline $\begin{array}{l}\text { Our } \\
\text { reduced } \\
\text { categories: }\end{array}$ & $\begin{array}{l}\text { Never } \\
\text { considered }\end{array}$ & $\begin{array}{l}\text { Entrepren } \\
\text { intentions }\end{array}$ & $\begin{array}{l}\text { eurial } \\
\text { /efforts }\end{array}$ & $\begin{array}{l}\text { Exit in } \\
\text { imagined } \\
\text { market }\end{array}$ & \multicolumn{2}{|c|}{ Business owner } & \multicolumn{2}{|c|}{ Exit in real market } \\
\hline
\end{tabular}

the impact of the personal and ecological characteristics on the odds of "failure" relative to the reference category (i.e. "young business" and "mature business"), but we also focus on the odds of "sell-off" relative to this reference category (see Table 2).

In sum, we perform a multinomial logit regression with six categories: "never considered", a combination of "thinking" and "taking steps", "gave up", a combination of "young business" and "mature business", "failure", and "sell-off". First, the focus will be on analyzing the odds of "gave up" relative to "thinking" and "taking steps" to explain imagined exit. Second, we will focus on the odds of "failure" relative to "young business" and "mature business" and subsequently, on "sell-off" relative to "young business" and "mature business". Our main analysis thus boils down to three investigations with two reference categories. The very nature of the multinomial logit model also gives us the opportunity to investigate which individual characteristics have an effect on the selection into entrepreneurship. To be more precise, we will also investigate the odds of "thinking" and "taking steps" relative to "never considered" and the odds of "young business" and "mature business" relative to "never considered". Note that the choice of the reference category does not influence the results of the multinomial logit model.

The explanatory variables used in the present study can be divided into two types: personal characteristics and ecological (environmental) characteristics.

Personal characteristics: gender, age, level of education, and self-employed parents. Gender ( male $=1$; female $=0$ ) and self-employed parents (at least one of the parents is/was self-employed $=1$; otherwise $=0$ ) are the obvious dummy variables. The first variable is only taken into account as a control variable. Age is measured as the current age - in years — of the respondent (not necessarily at time of exit, which then most likely happened at a younger age). ${ }^{8}$ We also include age squared to allow for

\footnotetext{
${ }^{8}$ Ideally, we would have had values of the explanatory variables at the time of exit. For example, we acknowledge that age at the time of imagined or real exit is preferred as the explanatory variable here, but we do not know how many years ago the exit took place.
} 
non-monotonic relationships. "Age when finished full education" is used as a continuous approximation of the level of education. ${ }^{9}$

Descriptive analyses reveal that $28 \%$ of the individuals in this sample have at least one (former) self-employed parent. The averages of age and education are 46.96 and 19.81 years (with standard deviations of 16.84 and 6.18 years), respectively. These numbers are based on 14,545 observations. Earlier, we have seen that 19,400 respondents specified their level of engagement in the entrepreneurial process. Our estimation sample, however, will consist of 14,545 observations. This number is retrieved such that no single observation contains missing values on any of the variables that will be included in the analyses that follow. In other words, our multinomial logit regression will be based on 14,545 observations. The difference of 4855 observations between the earlier sample of 19,400 observations and the present estimation sample is thus the result of missing values for any of the variables that will be used to explain imagined and real exit.

Next to these "usual suspects" in demographic research, we have also included an often used entrepreneurial personality variable, namely risk tolerance. Risk tolerance is captured by the following statement: "One should not start a business if there is a risk it might fail". For this statement the risk tolerance dummy takes value 1 if "disagree" or "strongly disagree", and 0 if "agree" or "strongly agree" is given as response. ${ }^{10}$ The average value of this variable is 0.50 .

Ecological characteristics: We have explicitly taken into account different elements of the environment: the perceived environmental constraints, the degree of urbanization (a proxy for resource munificence and competition), and the national institutional system. The perceived environmental constraints are measured using three variables: the perception of lack of available financial support, the perception of complexity of administrative procedures, and the perception of lack of sufficient information on setting up an own business. These variables are captured, respectively, by the question: "Do you strongly agree, agree, disagree or strongly disagree with the following statements?” given the following statements:

"It is difficult to start one's own business due to a lack of available financial support."

"It is difficult to start one's own business due to the complex administrative procedures."

\footnotetext{
${ }^{9} \mathrm{~A}$ small fraction of 319 individuals in the original sample responded that they never attended full time education. These observations have value 12 for the education level to reflect possible entry to the labor market. Also, all answers between 1 and 11 have been recoded into 12 (493 observations in the original sample).

${ }^{10}$ Clearly, this is a crude indicator of risk attitudes and calling this dummy "risk tolerance" may be abusive. Nevertheless, in the absence of a better measure, we believe it provides some information on how taking risks is perceived by the respondent.
} 
Table 3 Categorization of national institutional systems

\begin{tabular}{|c|c|c|}
\hline Category & Countries & Relative contribution \\
\hline $\begin{array}{l}\text { Corporatist/Social } \\
\text { Insurance }\end{array}$ & $\begin{array}{l}\text { Austria, Belgium, France, Germany, Italy, } \\
\text { Luxembourg, Netherlands }\end{array}$ & $\begin{array}{l}0.28 \text { (4111 } \\
\text { observations) }\end{array}$ \\
\hline Southern Europe & Cyprus, Greece, Malta, Portugal, Spain & 0.21 (3126 obs.) \\
\hline Post-communist & $\begin{array}{l}\text { Czech Republic, Estonia, Hungary, Latvia, } \\
\text { Lithuania, Poland, Slovakia, Slovenia }\end{array}$ & 0.26 (3797 obs.) \\
\hline $\begin{array}{l}\text { Social democratic/ } \\
\text { Universalist/Scandinavian }\end{array}$ & Denmark, Finland, Iceland, Norway, Sweden & 0.10 (1505 obs.) \\
\hline Liberal/Anglo-Saxon ${ }^{a}$ & Ireland, United Kingdom, United States & 0.14 (2006 obs.) \\
\hline
\end{tabular}

${ }^{\mathrm{a}}$ Used as reference category in regressions.

"It is difficult to obtain sufficient information on how to start a business."

For each statement a dummy variable is constructed. The dummy variables take value 1 in the case of "agree" or "strongly agree" for the four statements, and 0 if "disagree" or "strongly disagree" is answered. The averages are $0.79,0.74$, and 0.51 , respectively, across the estimation sample.

The degree of urbanization is measured by asking the respondent in which kind of locality he/she lives. Three mutually exclusive answer categories are possible: metropolitan zone, urban center, and rural zone. Rural zone is taken as the base category. The percentages of metropolitan, urban, and rural areas in the estimation sample are $0.22,0.43$, and 0.36 , respectively.

Finally, the country-specific institutional systems are taken into account using the categorization of institutional systems by Esping-Andersen (1999) (see Table 3). In this categorization, Liberal/Anglo-Saxon countries ${ }^{11}$ are taken as the base. Therefore, the coefficients associated with these variables are to be interpreted as the impact of being in the corresponding institutional system rather than being in Liberal/ Anglo-Saxon. The relative contribution of each institutional system to the estimation sample is also given in Table 3 (i.e. the averages of the constructed variables).

\section{Results}

How can exit in imagined and real markets be explained? Table 4 presents the results of the multinomial logit regression in terms of odds ratios. The estimates represent

\footnotetext{
${ }^{11}$ This category is similar to the "Liberal Market Economy" in the "varieties of capitalism" literature (Hall and Soskice, 2001; Casper and Whitley, 2004).
} 
Table 4 Estimation results multinomial logit model explaining imagined and real exit (odds ratios)

\begin{tabular}{|c|c|c|c|}
\hline \multirow{2}{*}{$\begin{array}{l}\text { Type of exit } \\
\text { Odds under investigation }\end{array}$} & Imagined exit & $\begin{array}{l}\text { Real exit due to } \\
\text { failure }\end{array}$ & $\begin{array}{l}\text { Real exit due to } \\
\text { sell-off }\end{array}$ \\
\hline & $\begin{array}{l}\text { "Thinking" and } \\
\text { "Taking steps" }\end{array}$ & $\begin{array}{l}\text { "Young business" } \\
\text { and "Mature } \\
\text { business" }\end{array}$ & $\begin{array}{l}\text { "Young business" } \\
\text { and "Mature } \\
\text { business" }\end{array}$ \\
\hline \multicolumn{4}{|l|}{ Personal determinants } \\
\hline Risk tolerance & $0.831 * * *(0.053)$ & $0.687^{* * *}(0.080)$ & $0.862^{*}$ \\
\hline Education & $0.972^{* * *}(0.005)$ & $0.985 \quad(0.009)$ & $0.982 * * *(0.006)$ \\
\hline Self-employed parents & $0.732^{* * *}(0.052)$ & $0.598^{* * *}(0.078)$ & $0.887 \quad(0.075)$ \\
\hline Male & $0.949 \quad(0.059)$ & $0.789 * * \quad(0.088)$ & $0.728^{* * *}(0.058)$ \\
\hline Age & $1.082^{* * *}(0.012)$ & $0.973 \quad(0.025)$ & $0.910^{* * *}(0.016)$ \\
\hline $\mathrm{Age}^{2}$ & $1.000 * *(0.000)$ & $(0.000)$ & $1.001^{* * *}(0.000)$ \\
\hline \multicolumn{4}{|l|}{ Ecological determinants } \\
\hline $\begin{array}{l}\text { Perceived lack of } \\
\text { financial support }\end{array}$ & $(0.079)$ & $1.574^{* * *}(0.233)$ & $1.186^{*}$ \\
\hline $\begin{array}{l}\text { Perceived administrative } \\
\text { complexities }\end{array}$ & $(0.077)$ & $(0.145)$ & $1.216^{* *}(0.111)$ \\
\hline $\begin{array}{l}\text { Perceived insufficient } \\
\text { information }\end{array}$ & $(0.065)$ & $(0.126)$ & $(0.083)$ \\
\hline Metropolitan & $0.856^{*} \quad(0.073)$ & $1.557^{* * *}(0.236)$ & $(0.121)$ \\
\hline Urban & $0.879 * \quad(0.062)$ & $1.315^{* *}(0.174)$ & $(0.095)$ \\
\hline Corporatist & $2.095^{* * *}(0.209)$ & $0.647^{* *}(0.127)$ & $0.781 * * \quad(0.097)$ \\
\hline Southern Europe & $2.043^{* * *}(0.221)$ & $0.827 \quad(0.157)$ & $0.535^{* * *}(0.071)$ \\
\hline Post-communist & $0.756^{* * *}(0.077)$ & $(0.163)$ & $0.402^{* * *}(0.054)$ \\
\hline Social democratic & $1.056 \quad(0.136)$ & $(0.154)$ & $0.918 \quad(0.131)$ \\
\hline \multicolumn{4}{|l|}{ Further statistics } \\
\hline Number of observations & 14,545 & & \\
\hline McFadden $R^{2}$ & 0.09 & & \\
\hline Nagelkerke $R^{2}$ & 0.25 & & \\
\hline \multicolumn{4}{|c|}{ LR $\chi^{2}$ (75 degrees of freedom) 3968.54 ( $P$-value $\left.<1 \%\right)$} \\
\hline Log likelihood at intercepts & $-21,760.02$ & & \\
\hline Log likelihood at convergence & $-19,775.75$ & & \\
\hline
\end{tabular}

Standard errors are between parentheses; estimated intercepts are not shown.

Estimates significantly different from unity at the $0.01\left(^{* * *}\right)$, the $0.05\left(^{* *}\right)$, and the $0.10\left(^{*}\right)$ level. 
the impact of the personal and ecological variables on the odds (ratio of two probabilities) of imagined or real exit relative to the appropriate reference category. ${ }^{12}$ More specifically, the first column of results in Table 4 refers to the explanation of imagined exit: the estimates describe the impact of the corresponding variable on the odds of "gave up" relative to "thinking" and "taking steps". Given an estimate above unity and holding all other variables equal, an increase in a variable raises the probability of belonging to the engagement level "gave up" as compared to the reference category consisting of the engagement levels "thinking" and "taking steps". The opposite is true for an estimate below unity. The second column of results in Table 4 focuses on the odds of "failure" relative to "young business" and "mature business" while the last column of results explains the odds of "sell-off" relative to "young business" and "mature business". Standard errors are also displayed in Table 4 next to asterisks denoting significant differences of the estimates from unity at the $\left.0.01{ }^{* * *}\right)$, the $0.05\left(^{* *}\right)$, and the $0.10\left(^{*}\right)$ level.

In the present section, we will first elaborate on the specification of the multinomial logit model. Subsequently, we present and discuss the effects of personal characteristics on entrepreneurial exit in imagined and real markets. This will be followed by a presentation and discussion of the effects of ecological characteristics.

\subsection{Model specification}

The odds of any pair of categories in the multinomial logit model depend only on the characteristics of the two categories under consideration and are independent of the number of categories. This property is known as the independence of irrelevant alternatives (IIA, McFadden, 1973). Several tests have been proposed to assess whether this property can theoretically be sustained (McFadden et al., 1981; Small and Hsiao, 1985; Hausman and McFadden, 1984). The performance of these tests has been investigated by Fry and Harris $(1996,1998)$ and Cheng and Long (2007). The latter authors even suggest (p.598) that "(...) tests of the IIA assumption that are based on the estimation of a restricted choice set are unsatisfactory for applied work." Long and Freese (2006: 244) state that the tests above-that are based on

\footnotetext{
${ }^{12}$ The analysis of the odds of "gave up" versus "thinking" and "taking steps" contains respondents that indicate to be self-employed at the same time. Next to the question on engagement levels the questionnaire asks respondents to specify their current occupation: "As far as your current occupation is concerned, would you say you are self-employed, in paid employment, or would you say that you are without a professional activity?". It could be that these respondents (those that indicate to be selfemployed while being in "gave up", "thinking", or "taking steps") are "imagined portfolio entrepreneurs" in that they have taken steps or have thought about setting up a business next to their present business. Excluding these imagined portfolio entrepreneurs (346 observations in the original sample) does not result in different conclusions.
} 
estimating restricted choice sets_can produce "contradictory results". In our application we expect, on theoretical grounds, the IIA property not to be a concern because of the dissimilar structure of our engagement levels (Amemiya, 1981). This dissimilar structure is emphasized by the fact that we are unable to combine any pair of categories (Cramer and Ridder, 1991).

The IIA property originates from the fact that the underlying disturbance terms of the categories are uncorrelated and homoscedastic by definition. This may be an unrealistic assumption in our case as there is a possibility that common omitted variables affect one or more engagement levels simultaneously. Alternative models that allow for cross-categorical disturbance correlation include the multinomial probit model (Hausman and Wise, 1978; for the relative benefits and liabilities of multinomial logit and multinomial probit, see Dow et al., 2004), the nested logit model (Domencich and McFadden, 1975; Ben-Akiva and Lerman, 1985), and the mixed logit model (Train, 2003). The multinomial probit model and the mixed logit model cannot be considered in our context as we do not have the availability of country-specific variables in our dataset, which are needed to relax the zero correlation between disturbance terms. We abstain from using the nested logit model here because one may think of multiple specific nesting structures of the engagement levels; choosing one such nesting would thus be subjective. In this context, the following argument by Greene (2003: 727) applies: "There is no well-defined testing procedure for discriminating among tree structures, which is a problematic aspect of the model." Also, the issue of uncorrelated disturbance terms remains present between categories in one branch in a nested logit model.

Because it is difficult to define residuals in multinomial choice models, one has to rely on pseudo $R^{2}$ measures to assess the fit of these models. One such a measure has been proposed by McFadden (1973) that compares the log likelihood of the model with only intercept parameters with the log likelihood at convergence. As McFadden (1979: 307) points out, the values of these types of indices "tend to be considerably lower than those of the $R^{2}$ index and should not be judged by the standards for a 'good fit' in ordinary regression analysis." In our case, McFadden's $R^{2}$ amounts to 0.09 as can be seen in Table 4. Another definition has been proposed by Maddala (1983), which was revised by Nagelkerke (1991) to allow $R^{2}$ to lie between 0 and 1 . The Maddala $R^{2}$ and Nagelkerke $R^{2}$ equal 0.24 and 0.25 in our case, respectively. Another method to assess the fit of the model is to examine the observed and predicted frequencies of all categories. In the estimation sample, the true frequencies are $0.46,0.17,0.15,0.12,0.03$, and 0.08 for "never considered," "thinking"/ "taking steps," "gave up," "young business"/“mature business," "failure," and "sell-off," respectively. For each individual we now compute the predicted probabilities for all categories. Averaging these numbers across all individuals delivers predictions $(0.46$, $0.17,0.15,0.11,0.03$, and 0.08 ) that show huge resemblance with our previously presented numbers. 


\subsection{Personal characteristics}

Unambiguously, and in contrast to our expectations, risk tolerance appears to have a negative influence on exit in imagined markets and on both types of exit in real markets. Repositioning the multinomial logit model with another reference category (i.e. focusing on the odds of "thinking" and "taking steps" relative to "never considered") reveals that risk tolerance has a positive impact on having entrepreneurial intentions or undertaking efforts to start a business (Grilo and Thurik, 2008). These results are displayed in the first column of results in Table 5.

Table 5 Estimation results multinomial logit model explaining selection into entrepreneurship (odds ratios)

\begin{tabular}{|c|c|c|}
\hline Type of selection & $\begin{array}{l}\text { Selection into } \\
\text { entrepreneurial } \\
\text { intentions/efforts }\end{array}$ & $\begin{array}{l}\text { Selection into } \\
\text { business ownership }\end{array}$ \\
\hline Odds under investigation & $\begin{array}{l}\text { "Thinking" and } \\
\text { "Taking steps" versus } \\
\text { "Never considered" }\end{array}$ & $\begin{array}{l}\text { "Young business" and } \\
\text { "Mature business" versus } \\
\text { "Never considered" }\end{array}$ \\
\hline \multicolumn{3}{|l|}{ Personal determinants } \\
\hline Risk tolerance & $1.400 * * *(0.074)$ & $1.579 * * *(0.096)$ \\
\hline Education & $1.047^{* * *}(0.005)$ & $1.033^{* * *}(0.005)$ \\
\hline Self-employed parents & $1.317^{* * *}(0.077)$ & $1.805^{* * *}(0.114)$ \\
\hline Male & $1.631^{* * *}(0.085)$ & $3.121 * * *(0.184)$ \\
\hline Age & $1.015^{*} \quad(0.009)$ & $1.269^{* * *}(0.017)$ \\
\hline $\mathrm{Age}^{2}$ & $0.999 * * *(0.000)$ & $0.997^{* * *}(0.000)$ \\
\hline \multicolumn{3}{|l|}{ Ecological determinants } \\
\hline Perceived lack of financial support & $1.189 * * * \quad(0.078)$ & $0.880^{*} \quad(0.062)$ \\
\hline Perceived administrative complexities & $0.908 \quad(0.055)$ & $0.658^{* * *}(0.044)$ \\
\hline Perceived insufficient information & $(0.052)$ & $1.024 \quad(0.064)$ \\
\hline Metropolitan & $(0.070)$ & $0.895 \quad(0.071)$ \\
\hline Urban & $(0.059)$ & $0.828^{* * *}(0.055)$ \\
\hline Corporatist & $0.471 * * *(0.039)$ & $0.741 * * *(0.073)$ \\
\hline Southern Europe & $0.484^{* * *}(0.044)$ & $1.272^{* *} \quad(0.130)$ \\
\hline Post-communist & $1.087 \quad(0.088)$ & $1.356^{* * *}(0.136)$ \\
\hline Social democratic & $0.671^{* * *}(0.068)$ & $1.058 \quad(0.122)$ \\
\hline
\end{tabular}

Standard errors are between parentheses; estimated intercepts are not shown. Model statistics are displayed in Table 4.

Estimates significantly different from unity at the $0.01\left(^{* * *}\right)$, the $0.05\left(^{* *}\right)$, and the $0.10\left(^{*}\right)$ level. 
The impact of risk tolerance on entry into self-employment is illustrated in the second column of results in Table 5, which concentrates on the odds of "young business" and "mature business" relative to "never considered" (Grilo and Thurik, 2008). This impact is being "compensated" by the strong negative influence of risk tolerance on "failure" relative to "young business" and "mature business" in that an additional analysis shows that risk tolerant individuals are not more likely to be in the "failure" engagement level relative to "never considered". These additional analyses also reveal that the odds of "gave up" relative to "never considered" and "sell-off" relative to "never considered" are significantly influenced by risk tolerance.

Thus, given that one belongs to either of the two markets, risk tolerant individuals (who are more likely to be present in these markets) are also less likely to exit. The present research thus shows that risk tolerance not only discriminates between (potential) entrepreneurs and those without any entrepreneurial activity, but it also discriminates between individuals that currently experience imagined and real market conditions and those that have exited either of the two markets.

A clear significant negative effect for education is found for exit in imagined as well as from real markets due to sell-off. The importance of education might indicate that higher educated persons are better able to recognize high value entrepreneurial opportunities which lower the probability of exit in imagined markets. This strong effect of ability seems to offset the high opportunity costs of entrepreneurship for highly educated people. Hence, educational level does not only increase the probability that an individual undertakes serious activities to start a business (first column of Table 5); it also facilitates the persistence of realizing these intentions and/or efforts into business ownership given the lower probability of exiting the imagined market (Table 4) and given the higher probability of selection into business ownership (Table 5). An important observation in this context is that the odds of "failure" relative to currently having a business are not significantly affected by the education level.

According to our expectations, persons with self-employed parents are less likely to give up their entrepreneurial intentions and efforts, and once they have started as a business owner, they are less likely to fail. This might be explained by the indirect learning effect, i.e. observing entrepreneurial actions of role models (Aldrich and Kim, 2007). While Table 5 shows that respondents with a self-employed parent have a much higher likelihood of having taken steps toward starting a business or of having run a business, we can also conclude from Table 4 that respondents without self-employed parents have a much higher likelihood of having given up these steps or of having failed. The impact of this variable on entrepreneurial exit is so strong that the odds of "gave up" relative to "never considered" and "failure" relative to "never considered" are not significantly affected by having a self-employed parent.

Age seems to have a positive linear effect on exit in imagined markets (irrelevant turning point at which the impact of age on the odds ratio becomes negative), and on 
exit due to failure. ${ }^{13}$ Furthermore, there exists a U-shaped relationship between age and the odds of "sell-off" relative to "young business" and "mature business" (turning point at 32 years).

\subsection{Ecological characteristics}

While perceived environmental constraints are hardly related to exit, urban and metropolitan locations have the expected negative effect on exit in imagined markets (albeit only significant at 10\%). Note that the degree of urbanization does not have an influence on having entrepreneurial intentions and/or undertaking efforts to start a business (first column of Table 5). Furthermore, being located in a metropolitan or an urban area increases the odds of "failure" relative to "young business" and "mature business". Hence, the effect of real competition in metropolitan and urban environments seems to be more relevant than the imagined effect. Individuals in urban and metropolitan environments seem to hang on to their entrepreneurial intentions much more and once they enter real markets they more often fail.

We first note (based on Table 5) that all institutional regimes (relative to the Anglo-Saxon regime) have an equal or lower odds of "thinking" and "taking steps" relative to "never considered". Put it differently, individuals in the Anglo-Saxon regimes have the highest likelihood to undertake efforts to start a business. Table 4 additionally shows that the corporatist regime has the expected positive effect on exit in imagined markets: individuals in this welfare state regime thus have fewer incentives to maintain their entrepreneurial intentions and efforts relative to individuals in Anglo-Saxon regimes. Next to individuals in corporatist regions, it also turns out that Southern Europeans are twice as likely to have given up entrepreneurial intentions and/or efforts relative to individuals in Anglo-Saxon regimes. We also see (last column of Table 5) that individuals in corporatist regimes have the smallest probability of all regimes to own a business currently. Finally, and according to our expectations, the corporatist welfare and social democratic welfare regimes decrease the odds of "failure" versus "young business" and "mature business", relative to Anglo-Saxon countries.

Table 6 summarizes the empirical evidence of our analyses. ${ }^{14}$

\footnotetext{
${ }^{13}$ Additional analyses excluding the squared age term confirm this finding (the estimate belonging to the linear age term is significantly different from unity at $5 \%$ ).

${ }^{14} \mathrm{An}$ interesting research question relates to changing patterns over time by conducting longitudinal research methods. A starting point is to perform the same analysis with an older version of the "Flash Eurobarometer Survey on Entrepreneurship", i.e. No. 160 from 2004 which was used in Grilo and Thurik (2005) and Van der Zwan et al. (2010). There is no distinction between real exit due to business failure and due to sell-off in this 2004 version. The analysis of exit in imagined markets (2007 results are in the first column of Table 4) establishes the following results. Concerning personal characteristics we observe that risk tolerance, education, and self-employed parents do
} 
Table 6 Empirical evidence concerning exit in imagined and real markets

\begin{tabular}{llll}
\hline Type of exit & Imagined & Real exit \\
& exit & due to failure & $\begin{array}{l}\text { Real exit } \\
\text { due to sell-off }\end{array}$ \\
\hline Risk tolerance & - & - & - \\
Education & - & 0 & - \\
Self-employed parents & - & - & 0 \\
Male & 0 & - & - \\
Age & + & + & U-shaped \\
Perceived environmental constraints & 0 & Partly + & 0 \\
Metropolitan/urban & - & + & - \\
Strong welfare state & + & - & \\
\hline
\end{tabular}

\section{Conclusion and discussion}

We present evidence on the determinants of entrepreneurial exit in real and imagined markets using a cross-sectional survey of some 20,000 individuals in European countries and the United States. Prospective business owners enter an imagined market when they start thinking about setting up a business or are taking preparatory steps. The novelty of our approach is in the comparison of ex-post selection (business failure in real markets) with ex-ante selection (in imagined markets). We have assessed the role of personal and ecological characteristics in the explanation of exit in real and imagined markets. Our analyses show that risk tolerance and having a self-employed parent have significant negative relations with exit in imagined markets and exit in real markets due to business failure. Ecological characteristics related to urbanization and welfare state regimes seem to have contrasting effects on exit in imagined markets as compared to exit in real markets. Urbanization has a negative effect on exit in imagined markets, but a positive effect on exit in real markets. Strong welfare regimes have a positive effect on exit in imagined markets, while they have a negative effect on exit in real markets.

not have significant effects (at 10\%) in 2004, while we find clear negative effects in 2007. Age has a positive linear effect on exit in imagined markets in both years. Furthermore, we see that perceived environmental constraints are not related to imagined exit, which is also the case in 2007. Urban and metropolitan locations again have negative effects. We note that in 2004 all institutional regimes (relative to the Anglo-Saxon regime) have higher odds of "gave up" versus "thinking" and "taking steps". The 2004 multinomial regression is based on 16,502 observations. Finally, our focus is on the odds of "thinking" and "taking steps" versus "never considered" (2007 results are in the first column of Table 5). There are no qualitative differences between 2004 and 2007, except that being located in a metropolitan or in an urban area increases this odds in 2004 and that perceived lack of financial support is not of significant importance in 2004. 
We could interpret our results from a "rational expectations" viewpoint: prospective entrants objectively assess the returns of entering the market as an entrepreneur. They make decisions on whether or not to enter as well as the timing and mode of entry in a manner that seeks to maximize expected profit in an uncertain environment (Helfat and Lieberman, 2002). While rational behavior of this sort may be a reasonable first approximation, numerous studies suggest that entrants often suffer from cognitive biases (Kahneman and Lovallo, 1993; Dosi and Lovallo, 1997). Individuals may be overly optimistic about their own entrepreneurial abilities, which would mean that such biases would contribute to "excessive" entry (i.e. relatively low quality entrants). This seems especially relevant when certain explanatory variables do not have an effect (or have a negative effect) on exit in imagined markets, but do have an effect (or have a positive effect) on exit in real markets. Our analyses suggest that the entry of individuals in metropolitan and urban areas might be too optimistic (with a negative effect on imagined exit and a positive effect on real exit due to failure). Camerer and Lovallo (1999) found evidence of excess market entry-entry into crowded markets that offered slim success chances-ostensibly instigated by individuals who held biased (e.g. overconfident) assessments of their competitive abilities. This can be prevented, if potential entrepreneurs become better informed about their chances of entrepreneurial success (and thus will be more likely to "give up"). The reverse phenomenon—under optimism—might also be prevalent: our analyses suggest that corporatist and Southern European welfare regimes seem to have this effect on their inhabitants.

Exit has been the central topic in this article. One of the key axioms in economics is that the least viable (productive) businesses will be eliminated due to selection pressures in the market, i.e. market selection (Bellone et al., 2008). As stated before, entrepreneurial exit does not necessarily equate to business exit in two ways: first, so called habitual entrepreneurs can exit a business while continuing with another business, and second, entrepreneurs can exit their business while the business continues to exist (the "sell-off" category in our analyses). In this article we have made the distinction between entrepreneurial exit due to business failure and due to sell-off. In that sense, we have addressed a shortcoming in much of the exit literature that has equated business failure with sell-offs within an overall category of business exit. However, we also know that many entrepreneurs stick to a marginal businessand thus an entrepreneurial career-because they have relatively low aspiration levels, while a subset of entrepreneurs close down profitable businesses because these businesses do not reach the high aspiration levels of these ambitious (often human capital rich) entrepreneurs (Gimeno et al., 1997). Even though we do not find a related positive effect of education on exit, the heterogeneity in aspiration levels questions the universal appropriateness of the evolutionary mechanism of "survival of the fittest". Some authors have also emphasized the evolutionary mechanism of "selection via differential growth" (Nelson and Winter, 1982). Such a mechanism is outside the scope of our empirical analyses. Even though 
we recognize the heterogeneity in businesses (ranging from marginal self-employed to the high-growth innovative industry leader; cf. Santarelli and Vivarelli, 2007), which is not taken into account in our analyses, we do still value the prevalence of the "survival of the fittest" mechanism. In a recent overview of the empirical industrial economics literature on growth and exit, Coad (2009) concludes that selection mainly operates via elimination of the least productive businesses and that the mechanism of selection via differential growth does not appear to be as strong.

Even though this article's main contribution is to the evolutionary economics research field, it contains some evidence that confirms the neo-classical approach to entrepreneurship. Although entrepreneurship is largely neglected in this branch of economics (see Bianchi and Henrekson, 2005), there are some key contributions which "explain" entrepreneurship by the risk preferences of individuals (Kihlstrom and Laffont, 1979). The empirical evidence in this article confirms the importance of risk tolerance in stepping up the "entrepreneurial ladder" (Van der Zwan et al., 2010) and more specifically, as a driver of entrepreneurial persistence in imagined and real markets.

Our article also contributes to the institutional literature on the effects of welfare state regimes (Esping-Andersen, 1999) and varieties of capitalism (Hall and Soskice, 2001) in a new way. This literature has largely neglected entrepreneurship or has only focused on entry (Casper, 2007). We have shown in this article that these institutions are also an important element in the explanation of entrepreneurial exit in real and imagined markets. The Anglo-Saxon regime, which is generally seen as the most fertile institutional system for entrepreneurship (Bosma et al., 2008), seems to have a negative effect on exit in imagined markets in comparison with the corporatist and Southern Europe regimes having positive effects, while the corporatist regime seems to have a negative effect on exit in real markets. Our findings redirect attention to the role of non-market selection environments next to market selection environments (Nelson and Winter, 1982). Future research should include a better categorization of the institutional environment next to the welfare state typologies (Freytag and Thurik, 2007).

An important indirect measure of market selection is captured by our ecological variables "metropolitan" and "urban" environments. In these high density environments competition between businesses is known to be much fiercer than in low density, rural environments (Audretsch, 1998; Caniëls, 2000; Fritsch and Mueller, 2008; Van Stel and Suddle, 2008). We find that individuals do not seem to let their aspirations be affected by this competition, and once they have entered the real market, their businesses are more likely to fail in metropolitan and urban environments than in rural environments. This may be interpreted as evidence for the prevalence of overoptimistic entrepreneurs in high density areas, in which the barriers to entry are (perceived to be) relatively low (Hoover and Vernon, 1959) and thus might lure relatively many low quality entrepreneurs into the market, who 
subsequently face the strong selection pressure in these highly competitive environments. More research is needed into the specific nature and effects of urban and metropolitan environments on different aspects of the entrepreneurial process (Bosma, 2010).

This article is one of the first steps into a research field of entrepreneurial decision-making in imagined and real markets. Further studies may build on our explorations and provide more specific variables and longitudinal research methods, and experimental research methods, in order to trace the causes of decision-making that precedes entrance into the market by entrepreneurs.

\section{Acknowledgements}

The authors would like to thank Reena Bhola for research assistance, and Rui Baptista, Isabel Grilo, Jonathan Levie, and two anonymous referees for comments on earlier versions of this article. Earlier versions have been presented at seminars at the Max Planck Institute of Economics in Jena, Imperial College London, and Erasmus University Rotterdam. This article has been written in collaboration with the research program SCALES, which is carried out by EIM and is financed by the Dutch Ministry of Economic Affairs.

\section{References}

Alchian, A. A. (1950), 'Uncertainty, evolution, and economic theory,' Journal of Political Economy, 58(3), 211-221.

Aldrich, H. E. and P. H. Kim (2007), 'A life course perspective on occupational inheritance: self-employed parents and their children,' in M. Ruef and M. Lounsbury (eds), Research on the Sociology of Organizations. Elsevier JAI: Amsterdam.

Aldrich, H. E. and G. Wiedenmayer (1993), 'From traits to rates: an ecological perspective on organizational foundings,' in J. A. Katz and R. H. Brockhaus (eds), Advances in Entrepreneurship, Firm Emergence, and Growth. Jai Press: Greenwich, CT, pp. 45-195.

Amemiya, T. (1981), 'Qualitative response models: a survey,' Journal of Economic Literature, 19, 1483-1536.

Amit, R., E. Muller and I. Cockburn (1995), 'Opportunity costs and entrepreneurial activity,' Journal of Business Venturing, 10(2), 95-106.

Audretsch, D. (1998), 'Agglomeration and the location of innovative activity,' Oxford Review of Economic Policy, 14(2), 18-29.

Audretsch, D. B., P. Houweling and A. R. Thurik (2004), 'Industry evolution: diversity, selection and the role of learning,' International Small Business Journal, 22(4), 331-348. 
Baldwin, J. R. and M. Rafiquzzaman (1995), 'Selection versus evolutionary adaptation: learning and post-entry performance,' International Journal of Industrial Organization, 13(4), 501-522.

Barnett, W. P., A-N. Swanson and O. Sorenson (2003), 'Asymmetric selection among organizations,' Industrial and Corporate Change, 12(4), 673-695.

Bartelsman, E., S. Scarpetta and F. Schivardi (2005), 'Comparative analysis of firm demographics and survival: evidence from micro-level sources in OECD countries,' Industrial and Corporate Change, 14(3), 365-391.

Bates, T. (1990), 'Entrepreneur human capital inputs and small business longevity,' The Review of Economics and Statistics, 72(4), 551-559.

Baumol, W. J. (2002), The Free-Market Innovation Machine: Analyzing the Growth Miracle of Capitalism. Princeton University Press: Princeton.

Bellone, F., P. Musso, L. Nesta and M. Quéré (2008), 'Market selection along the firm life cycle,' Industrial and Corporate Change, 17(4), 753-777.

Ben-Akiva, M. and S. R. Lerman (1985), Discrete Choice Analysis: Theory and Application to Travel Demand. MIT Press: Cambridge, MA.

Bianchi, M. and M. Henrekson (2005), 'Is neoclassical economics still entrepreneurless?,' Kyklos, 58, 353-377.

Blanchflower, D. G. and B. D. Meyer (1994), 'A longitudinal analysis of the young self-employed in Australia and the United States,' Small Business Economics, 6(1), $1-19$.

Blanchflower, D. G., A. Oswald and A. Stutzer (2001), 'Latent entrepreneurship across nations,' European Economic Review, 45(4-6), 680-691.

Bosma, N. (2010), The Geography of Entrepreneurial Activity and Regional Economic Development. A Multilevel Approach, Edward Elgar: Cheltenham.

Bosma, N., K. Jones, E. Autio and J. Levie (2008), Global Entrepreneurship Monitor 2007 Executive Report. Babson College/London Business School: Babson Park/London.

Box, M. (2008), 'The death of firms: exploring the effects of environment and birth cohort on firm survival in Sweden,' Small Business Economics, 31(4), 379-393.

Bruce, D. (2002), 'Taxes and entrepreneurial endurance: evidence from the self-employed,' National Tax Journal, 55(1), 5-24.

Burke, A. E., M. A. Nolan and F. R. FitzRoy (2008), 'What makes a die-hard entrepreneur? Beyond the 'employee or entrepreneur' dichotomy,' Small Business Economics, 31(2), 93-115.

Caliendo, M., M. F. Fossen and A. S. Kritikos (2009), 'Risk attitudes of nascent entrepreneursnew evidence from an experimentally validated survey,' Small Business Economics, 32(2), 153-167.

Camerer, C. and D. Lovallo (1999), 'Overconfidence and excess entry: an experimental approach,' American Economic Review, 89(1), 306-318. 
Caniëls, M. (2000), Knowledge Spillovers and Economic Growth. Regional Growth Differentials across Europe, Edward Elgar: Cheltenham.

Carroll, G. R. and O. M. Khessina (2005), 'The ecology of entrepreneurship,' in S. A. Alvarez, R. Agarwal and O. Sorenson (eds), Handbook of Entrepreneurship Research - Disciplinary Perspectives. Springer: Berlin.

Casper, S. (2007), Creating Silicon Valley in Europe. Public Policy Towards New Technology Industries, Oxford University Press: Oxford.

Casper, S. and R. Whitley (2004), 'Managing competences in entrepreneurial technology firms: a comparative institutional analysis of Germany, Sweden and the UK,' Research Policy, 33(1), 89-106.

Cefis, E. and O. Marsili (2005), 'A matter of life and death: innovation and firm survival,' Industrial and Corporate Change, 14(6), 1167-1192.

Cheng, S. and S. J. Long (2007), 'Testing for IIA in the multinomial logit model,' Sociological Methods \& Research, 35(4), 583-600.

Ciavarella, M. A., A. K. Buchholtz, C. M. Riordan, R. D. Gatewood and G. S. Stokes (2004), 'The big five and venture survival: is there a linkage?,' Journal of Business Venturing, 19(4), 465-483.

Coad, A. (2009), The Growth of Firms: A Survey of Theories and Empirical Evidence, Edward Elgar: Cheltenham.

Cooper, A. C. (1993), 'Challenges in predicting new firm performance,' Journal of Business Venturing, 8(3), 241-253.

Cramer, J. S. and G. Ridder (1991), 'Pooling states in the multinomial logit model,' Journal of Econometrics, 47(2-3), 267-272.

Cramer, J. S., J. Hartog, N. Jonker and C. M. Van Praag (2002), 'Low risk aversion encourages the choice for entrepreneurship: an empirical test of a truism,' Journal of Economic Behavior and Organization, 48(1), 29-36.

Davidsson, P. (2006), 'Nascent entrepreneurship: empirical studies and development,' Foundations and Trends in Entrepreneurship Research, 2(1), 1-76.

Deakin, J., M. Aitken, T. Robbins and B. J. Sahakian (2004), 'Risk taking during decisionmaking in normal volunteers changes with age,' Journal of the International Neuropsychological Society, 10, 590-598.

Delmar, F. and S. Shane (2004), 'Legitimating first: organizing activities and the survival of new ventures,' Journal of Business Venturing, 19(3), 385-410.

Domencich, R. and D. McFadden (1975), Urban Travel Demand: A Behavioral Analysis, North Holland Publishing Company: Amsterdam.

Dosi, G. and D. Lovallo (1997), 'Rational entrepreneurs or optimistic martyrs? Some considerations on technological regimes, corporate entries and the evolutionary role of decision biases,' in R. Garud, P. Nayyar and Z. Shapira (eds), Technological Innovation: Oversights and Foresights. Cambridge University Press: Cambridge. 
Dow, J. K. and J. W. Endersby (2004), 'Multinomial probit and multinomial logit: a comparison of choice models for voting research,' Electoral Studies, 23(1), 107-122.

Ekelund, J., E. Johannson, M. Järvelin and D. Lichtermann (2005), 'Self-employment and risk aversion—evidence from psychological test data,' Labour Economics, 12, 649-659.

Esping-Andersen, G. (1999), Social Foundation of Postindustrial Economies, Oxford University Press: Oxford.

Evans, D. S. and L. Leighton (1989), 'Some empirical aspects of entrepreneurship,' American Economic Review, 79(3), 519-535.

European Commission, 2004. SMEs in Europe 2003. Observatory of European SMEs2003, No. 7, Enterprise Directorate-General of the European Commission, Brussels.

Forbes, D. P. (2005), 'Are some entrepreneurs more overconfident than others?', Journal of Business Venturing, 20(5), 623-640.

Freytag, A. and A. R. Thurik (2007), 'Entrepreneurship and its determinants in a cross-country setting,' Journal of Evolutionary Economics, 17(2), 117-131.

Fry, T. R. L. and M. N. Harris (1996), 'A Monte Carlo study of tests for the independence of irrelevant alternatives property,' Transportation Research Part B: Methodological, 30(1), $19-30$.

Fry, T. R. L. and M. N. Harris (1998), 'Testing for independence of irrelevant alternatives: some empirical results,' Sociological Methods \& Research, 26(3), 401-423.

Fritsch, M. and P. Mueller (2008), 'The effects of new business formation on regional development over time: the case of Germany,' Small Business Economics, 30(1), 15-29.

Geroski, P. (2001), 'Exploring the niche overlaps between organizational ecology and industrial economics,' Industrial and Corporate Change, 10(2), 507-540.

Gimeno, J., T. B. Folta, A. C. Cooper and C. Y. Woo (1997), 'Survival of the fittest? Entrepreneurial human capital and the persistence of underperforming firms,' Administrative Science Quarterly, 42(4), 750-783.

Grilo, I. and J-M. Irigoyen (2006), 'Entrepreneurship in the EU: to wish and not to be,' Small Business Economics, 26(4), 305-318.

Grilo, I. and A. R. Thurik (2005), 'Latent and actual entrepreneurship in Europe and the US: some recent developments,' International Entrepreneurship and Management Journal, 1(4), $441-459$.

Grilo, I. and A. R. Thurik (2008), 'Determinants of entrepreneurial engagement levels in Europe and the US,' Industrial and Corporate Change, 17(6), 1113-1145.

Hall, P. A. and D. Soskice (2001), Varieties of Capitalism: the Institutional Foundations of Comparative Advantage, Oxford University Press: Oxford.

Hannan, M. T. and J. Freeman (1984), 'Structural Inertia and Organizational Change,' American Sociological Review, 49, 149-164.

Hausman, J. A. and D. McFadden (1984), 'Specification tests for the multinomial logit model,' Econometrica, 52(5), 1219-1240. 
Hausman, J. A. and D. A. Wise (1978), 'A conditional probit model for qualitative choice: discrete decisions recognizing interdependence and heterogeneous preferences,' Econometrica, 46(2), 403-426.

Helfat, C. E. and M. B. Lieberman (2002), 'The birth of capabilities: market entry and the importance of pre-history,' Industrial and Corporate Change, 11(4), 725-760.

Henrekson, M. (2005), 'Entrepreneurship: a weak link in the welfare state?,' Industrial and Corporate Change, 14(3), 437-467.

Holmes, T. J. and J. A. Schmitz (1990), 'A theory of entrepreneurship and its application to the study of business transfers,' Journal of Political Economy, 98(2), 265-294.

Holtz-Eakin, D., D. Joulfaian and H. Rosen (1994), 'Sticking it out: entrepreneurial survival and liquidity constraints,' Journal of Political Economy, 102(1), 53-75.

Hoover, E. M. and R. Vernon (1959), Anatomy of a Metropolis, Harvard University Press: Cambridge.

Huiban, J.-P. (2010), 'The spatial demography of new plants: urban creation and rural survival,' Small Business Economics, forthcoming, DOI: 10.1007/s11187-009-9228-0.

Hyytinen, A. and P. Ilmakunnas (2007), 'What distinguishes a serial entrepreneur?,' Industrial and Corporate Change, 16(5), 793-821.

Ilmakunnas, P. and J. Topi (1999), 'Microeconomic and macroeconomic influences on entry and exit of firms,' Review of Industrial Organization, 15(3), 283-301.

Jovanovic, B. (2004), 'The pre-producers, NBER Working Papers 10771,' National Bureau of Economic Research, Cambridge, MA.

Kahneman, D. and D. Lovallo (1993), 'Timid choices and bold forecasts: a cognitive perspective on risk taking,' Management Science, 39(1), 17-31.

Kihlstrom, R. E. and J.-J. Laffont (1979), 'A general equilibrium entrepreneurial theory of firm formation based on risk aversion,' Journal of Political Economy, 87(4), 719-748.

Knott, A. M. and H. Posen (2005), 'Is failure good?', Strategic Management Journal, 26(7), 617-641.

Lentz, B. F. and D. N. Laband (1990), 'Entrepreneurial success and occupational inheritance among proprietors,' Canadian Journal of Economics, 23(3), 563-579.

Lévesque, M. and M. Minniti (2006), 'The effect of aging on entrepreneurial behaviour,' Journal of Business Venturing, 21(2), 177-194.

Long, J. S. and J. Freese (2006), Regression Models for Categorical Dependent Variables Using Stata, Stata Press: Texas.

Maddala, G. S. (1983), Limited-Dependent and Qualitative Variables in Econometrics, Cambridge University Press: Cambridge, UK.

Mata, J. and P. Portugal (1994), 'Life duration of new firms,' Journal of Industrial Economics, 42(3), 227-245.

Mata, J., P. Portugal and P. Guimaraes (1995), 'The survival of new plants: start-up conditions and post-entry evolution,' International Journal of Industrial Organization, 13(4), 459-482. 
McFadden, D. (1973), 'Conditional logit analysis of qualitative choice behavior,' in P. Zarembka (ed.), Frontiers in Econometrics. Academic Press: New York, pp. 105-142.

McFadden, D. (1979), 'Quantitative methods for analyzing travel behaviour of individuals: some recent developments,' in D. A. Hensher and P. R. Stopher (eds), Behavioural Travel Modeling. Croon Helm: London.

McFadden, D., K. Train and W. B. Tye (1981), 'An application of diagnostic tests for the independence from irrelevant alternatives property of the multinomial logit model,' Transportation Research Board Record, 637, 39-46.

Metcalfe, J. S. (1997), Evolutionary Economics and Creative Destruction, Routledge: London.

Minniti, M. (2005), 'Entrepreneurship and network externalities,' Journal of Economic Behavior and Organization, 57(1), 1-27.

Nagelkerke, N. J. D. (1991), 'A note on the general definition of the coefficient of determination,' Biometrika, 78(3), 691-692.

Nelson, R. R. and S. G. Winter (1982), An Evolutionary Theory of Economic Change, Belknap Press/Harvard University Press: Cambridge.

Nicoletti, G., S. Scarpetta and O. Boylaud (1999), 'Summary indicators of product market regulation with an extension to employment protection legislation,' ECO Working paper no. 226, OECD, Paris.

Pakes, A., J. Porter, K. Ho and J. Ishii (2005), 'Moment inequalities and their application,' Manuscript, Harvard University.

Parker, S. C. and Y. Belghitar (2006), 'What happens to nascent entrepreneurs? An econometric analysis of the PSED,' Small Business Economics, 27(1), 81-101.

Reynolds, P. D. (1997), 'Who starts new firms? Preliminary explorations of firms-in-gestation,' Small Business Economics, 9(5), 449-462.

Reynolds, P. D., N. Bosma, E. Autio, S. Hunt, N. Bono, I. de Servais, P. Lopez-Garcia and N. Chin (2005), 'Global entrepreneurship monitor: data collection design and implementation 1998-2003,' Small Business Economics, 24(3), 205-231.

Santarelli, E. and M. Vivarelli (2007), 'Entrepreneurship and the process of firms' entry, survival and growth,' Industrial and Corporate Change, 16(3), 455-488.

Schäfer, D. and O. Talavera (2009), 'Small business survival and inheritance: evidence from Germany,' Small Business Economics, 32(1), 95-109.

Scott, M. and P. Rosa (1996), 'Opinion: has firm level analysis reached its limits? Time for a rethink,' International Small Business Journal, 14(4), 81-89.

Shane, S. and R. Khurana (2003), 'Bringing individuals back in: the effects of career experience on new firm founding,' Industrial and Corporate Change, 12(3), 519-543.

Shane, S. and S. Venkataraman (2000), 'The promise of entrepreneurship as a field of research,' Academy of Management Review, 25(12), 217-226.

Small, K. A. and C. Hsiao (1985), 'Multinomial logit specification tests,' International Economic Review, 26(3), 619-627. 
Sørenson, J. B. and O. Sorenson (2003), 'From conception to birth: opportunity perception and resource mobilization in entrepreneurship,' in J. Baum and O. Sorenson (eds), Geography and Strategy, Advances in Strategic Management, Vol. 20. JAI Press: Greenwich, CT, pp. 89-117.

Stam, E., D. B. Audretsch and J. Meijaard (2008), 'Renascent entrepreneurship,' Journal of Evolutionary Economics, 18(3), 493-507.

Stuart, T. and O. Sorenson (2003), 'The geography of opportunity: spatial heterogeneity in founding rates and the performance of biotechnology firms,' Research Policy, 32(2), 229-253.

Taylor, M. P. (1999), 'Survival of the fittest? An analysis of self-employment duration in Britain,' Economic Journal, 109(454), C140-C155.

Train, K. (2003), Discrete Choice Methods with Simulation, Cambridge University Press: Cambridge.

Van der Sluis, J., C. M. Van Praag and W. Vijverberg (2005), 'Entrepreneurship selection and performance: A meta-analysis of the impact of education in less developed countries,' World Bank Economic Review, 19(2), 225-261.

Van der Zwan, P., A. R. Thurik and I. Grilo (2010), 'The entrepreneurial ladder and its determinants,' Applied Economics, forthcoming.

Van Gelderen, M., A. R. Thurik and N. Bosma (2005), 'Success and risk factors in the pre-startup phase,' Small Business Economics, 24(4), 365-380.

Van Praag, C. M. (2003), 'Business survival and success of young small business owners,' Small Business Economics, 21(1), 1-17.

Van Praag, C.M. and M. Cramer (2001), 'The roots of entrepreneurship and labor demand: individual ability and low risk aversion,' Economica, 68(269), 45-62.

Van Stel, A. and K. Suddle (2008), 'The impact of new firm formation on regional development in the Netherlands,' Small Business Economics, 30(1), 31-47.

Westhead, P. and M. Wright (1998), 'Novice, portfolio and serial founders: are they different?,' Journal of Business Venturing, 13(3), 173-204.

Winter, S. G. (1971), 'Satisficing, selection, and the innovating remnant,' The Quarterly Journal of Economics, 85(2), 237-261. 